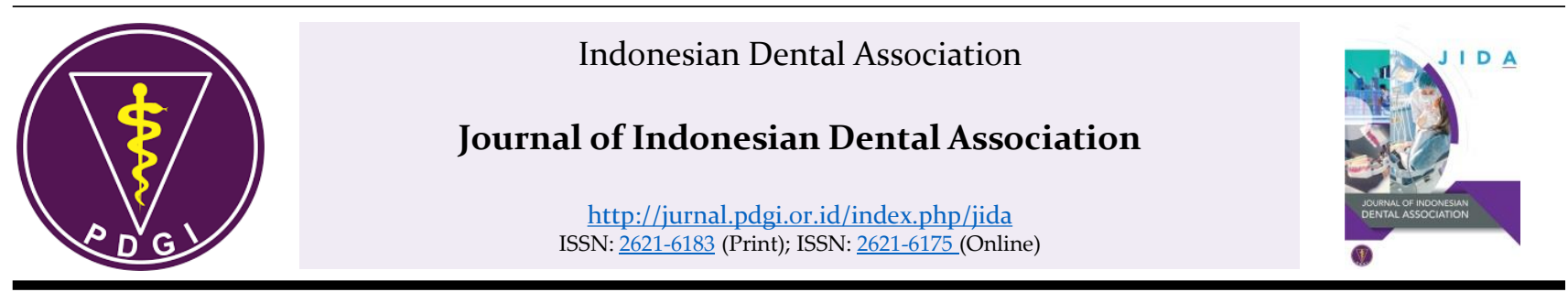

Literature Review

\title{
A Review of the Factors \\ Associated with Periodontal \\ Disease in the Elderly
}

\author{
Abdul Gani Soulissa ${ }^{1}$ \\ ${ }^{1}$ Department of Periodontic, Faculty of Dentistry, Trisakti University, Indonesia \\ Received date: October 15, 2019. Accepted date: January 10, 2020. Published date: February 20, 2020.
}

\section{KEYWORDS \\ elderly; \\ oral health care; \\ periodontal disease; \\ risk factors; \\ systemic disease; \\ systemic condition}

\begin{abstract}
The world's elderly population is growing faster than other age groups. The World Health Organization states that in 2020 , Indonesia's elderly population will reach $11.34 \%$ of the total population, or around 28.8 million people. The increasing number of elderly people can be a challenge for clinicians due to the degenerative changes caused by chronic diseases, treatment of chronic diseases, systemic conditions, and oral health care accessibility. The purpose of this study was to analyze the factors that increase the risk of periodontal disease in the elderly. Over the last few years, a lot of research has focused on identifying the relationship between periodontal disease and systemic disease as well as the link between periodontal disease and aging. Increased age relates directly and proportionally with increased prevalence and severity of periodontal disease. Furthermore, an increase in age causes a decrease in motoric function and an increase in comorbidities and their treatments in the elderly. The aging process causes cementum surface irregularities, inhibition of osteoblast activity, and reduction in the number of fibroblasts. Loss of attachment and alveolar bone resorption was affected by frequent exposure to other risk factors. The risk factors that influence the development of periodontal disease in the elderly include systemic diseases, such as diabetes mellitus and osteoporosis, systemic conditions, such as obesity, metabolic syndrome, and stress, treatment of systemic diseases, and limited access to oral health care. Although the potential link between periodontal disease and systemic disease has been established, the extent of this relationship has not yet been clearly explained. Understanding the factors that influence periodontal disease in the elderly is important because it may provide a better understanding of the treatment. The multiple risk factors that cause periodontal disease in elderly patients require special attention involving multidisciplinary teams.
\end{abstract}




\section{INTRODUCTION}

Indonesia has begun to enter an aging population phase in which an increase in life expectancy is accompanied by an increase in the elderly population, from 18 million people $(7.56 \%)$ in 2010 to 25.9 million people $(9.7 \%)$ in 2019 . The estimate for 2020 is 28.8 million people (11.34\%). It is predicted that the number of elderly people will continue to increase until it reaches 48.2 million people $(15.77 \%)$ in 2035 . The more developed a country is, the higher its number of elderly. In developed countries, elderly people make up $10 \%$ of the population, with Japan exceeding $30 \%$. This is caused by increased services in the health sector that provide increased opportunities for people to live longer and healthier lives. ${ }^{1-3}$

The aging process causes various physicalbiological, psychological, and social problems. Biologically, the elderly experience a continuous aging process characterized by decreased physical endurance and increased vulnerability to diseases that can cause death. This is due to changes in the structure and function of cells, tissues, and organ systems, including anatomical, morphological, and functional changes in the oral cavity. About $40 \%$ of elderly people complain of dry mouth, decreased strength of chewing (due to decreased mass of the muscles of mastication), and tooth loss, which affects esthetics and interferes with the process of communication. ${ }^{4,5}$

The aging process is influenced by degenerative diseases, environmental conditions, and lifestyle modifications, which lead to gradual changes in various organs. These factors can cause health problems, including periodontal disease. The prevalence of periodontal disease and its severity can increase with age. ${ }^{6}$ According to the World Health Organization (WHO), the prevalence of periodontal disease in people aged 65 years or older with a Community Periodontal Index (CPI) score of three or more was $45 \%$. Only $7 \%$ had no symptoms. ${ }^{6,7}$

The WHO has expressed concern that oral health in the elderly is widely ignored. Based on a global survey of the elderly, the WHO has called for public health actions by strengthening health promotion, integrating disease prevention, and improving age-friendly primary oral health care. Periodontal disease, including gingivitis and periodontitis, was reported to be one of the three main dental diseases reported by the WHO. ${ }^{8,9,10}$ The increasing number of elderly people poses a challenge to clinicians because advanced age is associated with degenerative changes caused by chronic diseases, treatment of chronic diseases, systemic conditions, and accessibility. In the elderly, there are several risk factors that can trigger periodontal disease or worsen its condition. Knowledge and understanding of periodontal disease risk factors in the elderly will help improve periodontal treatment in this population. ${ }^{6}$ The purpose of this study was to explain the factors that increase the risk of periodontal disease in the elderly.

\section{PERIODONTAL DISEASE IN THE ELDERLY}

Over the last few years, many studies investigating the relationship between periodontal disease and some systemic diseases have been conducted. The results of these studies generally conclude that there is a possible link between periodontal disease and systemic disease. Periodontal bacteria are believed to play a role as a risk factor for systemic disease. ${ }^{11}$ Periodontal disease can affect a person's systemic condition in two ways, namely through the bloodstream and inflammatory mechanisms. Conversely, systemic conditions can also affect periodontal conditions. ${ }^{12}$ However, according to some researchers, such as Yu-Kang and Gilthorpe, the relationship between periodontal disease and systemic disease can be lead to the influence of other factors, such as smoking, that may affect the development of both periodontal disease and systemic disease. ${ }^{13,14}$

The prevalence and severity of periodontal disease increase with age. Degenerative changes related to the aging process can increase susceptibility to periodontal disease. The loss of attachment and resorption of alveolar bone occurs as a result of frequent exposure to other risk factors. Changes related to the aging process, such as the use of medications, decreased immune function, and altered nutritional status, and other risk factors, increase one's susceptibility to periodontal disease. ${ }^{6,15}$

Vulnerable elderly people suffer from periodontal disease due to changes that occur in the tissues in the mouth, which may cause tooth loss that can interfere with mastication. The disruption of the function of mastication causes decreased nutrient absorption, which can reduce the quality of life of the elderly. The number of teeth has a positive correlation with individuals being satisfied with the condition of their mouths. Therefore, maintaining oral health in the elderly is important not only for having a healthy mouth condition but also for psychological well-being. $6,11,16$

\section{DIABETES MELLITUS}

The literature has consistently shown that diabetes mellitus is a systemic risk factor for periodontal disease and that it could have a major role in the initiation and progression of the disease. Diabetes mellitus is associated with damage to the periodontal ligament, which can exacerbate tooth loss. Gingival crevicular fluids and 
saliva in periodontitis patients with diabetes have a higher concentration of inflammatory mediators than non-diabetic periodontal disease patients. ${ }^{17}$

Over the next 20 years, the International Diabetic Federation estimates that the prevalence of diabetic patients in the Asia-Pacific region will reach 47\%.18 Much of this increase will be related to aging, obesity, poor diet, and unhealthy lifestyles. Asians tend to be more susceptible to diabetes. Diabetes is a major health problem with significant morbidity and mortality. The prevalence of elderly patients with undiagnosed diabetes is estimated to be around $20 \%$. 6,19

Diabetes mellitus is the result of impaired glucose metabolism due to decreased production or response to the insulin released by special cells in the islets of Langerhans in the pancreas. Most of its effects are on the peripheral blood vessels, which leads to vascular proliferation or decreased blood perfusion by thickening of the basement membrane. As a result, it can cause blindness, peripheral neuropathy, nephropathy, secondary infections, heart disease, and periodontal disease. Similar to periodontitis, type II diabetes commonly occurs in older adults. Moreover, uncontrolled type II diabetes is considered a risk factor that can worsen periodontitis. ${ }^{20}$

Diabetes mellitus can worsen the condition of periodontal disease. Poor glycemic control is closely related to disease progression and tooth loss in periodontal disease. Managing periodontal cases in the elderly requires good diabetes management to improve the results of periodontal treatment. ${ }^{21}$

\section{OSTEOPOROSIS}

Osteoporosis is a very common medical condition that affects $5 \%$ of the world's population. ${ }^{22}$ It is a systemic disorder characterized by reduced bone mineral density that can thereby increase the risk of fractures, especially of the hip. The US NHANES III data show that $13-18 \%$ of women and 3-6\% of men have osteoporosis. ${ }^{6}$ According to another study, the prevalence of osteoporosis in the world is very high, affecting one out of three women aged 60-70 years old and two out of three women older than 80 years of age. ${ }^{23}$ In a systematic review, Martinez-Maestre et al. suggested that osteoporosis is associated with increased tooth loss and could be linked to periodontal disease, although there is a lack of conclusive evidence. However, data show that a sizable proportion of older people may have dental problems due to osteoporosis, especially women. ${ }^{6,24}$

There are several factors that can affect the integrity of periodontal tissue in patients with osteoporosis. These include bacterial infiltration into the periodontal tissue, an increased number of pro-inflammatory cytokines, and changes in alveolar bone structure that are caused by decreased estrogen levels. ${ }^{25}$ There are two mechanisms that can potentially explain the relationship between osteoporosis and alveolar bone resorption. The first mechanism is that low bone mineral density in the alveolar bone triggers alveolar bone loss such that tooth loss occurs more quickly. The second mechanism is that decreased estrogen production can activate cytokines that increase osteoclast activity while decreasing osteoblast activity, resulting in alveolar bone resorption. ${ }^{26}$

\section{STRESS}

Elderly patients often suffer from systemic diseases. Old age weakens the body and puts limitations on physical activity, which often triggers stress in the elderly. Health, intelligence, financial capacity, ease in physical activity, and skills gradually decrease with age. Elderly patients with stress have a greater risk of suffering from periodontal disease. Stress is associated with poor oral hygiene, increased glucocorticoid secretion, which can suppress immune function, and increased insulin resistance, which can potentially increase the risk of periodontitis. ${ }^{27}$

\section{OBESITY}

Obesity is associated with many health problems, including stroke, cancer, diabetes, and cardiovascular disease. It has been shown to increase the risk of periodontal disease. Obesity is often associated with poor lifestyle, resulting in chronic inflammation, which can occur easily and may affect susceptibility to periodontal disease. ${ }^{6}$ Some researchers have suggested that obesity has a close relationship with periodontal disease. A number of researchers have found that the prevalence of periodontal disease is higher in obese people than in people of normal weight. The function of many adipocytes is to produce TNF- $\alpha$ can trigger inflammation in the periodontal tissue, which is why obese people often have more periodontal inflammation than non-obese people. ${ }^{28,29}$

\section{METABOLIC SYNDROME}

Metabolic syndrome is a serious medical condition that consists of abdominal obesity, dyslipidemia, hyperglycemia, and hypertension. It can increase the risk of diabetes type II and cardiovascular disease. In Caucasians, abdominal obesity is defined as a waist circumference of more than $100 \mathrm{~cm}$ in men and $90 \mathrm{~cm}$ in women. These numbers are lower for Asians. Research in Japan has shown that individuals with metabolic syndrome have a much greater risk of periodontal disease. $^{6}$ 
Diabetes, obesity, and metabolic syndrome could have a major impact not only on the prevalence and incidence of periodontal disease in an aging population but also for the dental profession because of the potentially high burden of disease management. Therefore, a multidisciplinary team is needed for the management of periodontal disease in elderly patients with systemic conditions. ${ }^{6}$

\section{MEDICATION CONSUMPTION}

In general, diseases in the elderly are chronic conditions. As a result, elderly people take systemic medications for extended periods of time. Thomson explained that most elderly people consume a number of different medications that can have oral side effects, such as xerostomia. Xerostomia can increase the risk of periodontal disease. ${ }^{6}$

Susceptibility to infections and periodontal disease increases when salivary flow decreases. The most common medications that can decrease salivary flow and produce oral dryness include tricyclic antidepressants, atropine, antihistamines, and beta blockers. Some medications, such as phenytoin, cyclosporine, and nifedipine, can also induce abnormal growth of gingival tissue and cause gingival hyperplasia. This makes it difficult to remove subgingival plaque, which can further aggravate periodontal disease. ${ }^{6,17}$

\section{ORAL HEALTH CARE ACCESSIBILITY}

As the number of elderly people increases, there can be social and economic impacts as well as an increase in the old age dependency ratio. Elderly patients generally have several chronic diseases, decreased organ function, and nutritional problems. Therefore, elderly patients require comprehensive and accessible health services. In addition, the level of independence is reduced in the elderly, which places limitations on obtaining health services. Limitations to obtaining health services for the elderly include financial barriers, lack of access to remote health service locations, health services not being accommodating to the elderly, or even a lack of awareness of the importance of oral health care for the elderly because they consider oral dysfunction to be a consequence of the aging process. ${ }^{6,11}$

Because of the importance of health services for the elderly, Ettinger and Beck suggested that the elderly population can be divided into three functional groups based on their ability to seek dental health services: (1) elderly people who are functionally capable and constitute a group of elderly people that can access health care independently using their own vehicle or public transportation; (2) elderly people who constitute a group of elderly people who have lost some of their independence but still live in the community with the help of family and friends or professional support services, such as nurses; and (3) elderly people who are more functionally dependent and constitute a group of elderly people who are unable to survive in the community independently and cannot live alone. ${ }^{11,12}$

The limitations to obtaining health services for elderly people with systemic diseases may cause their health conditions to be uncontrolled, which makes them vulnerable to complications of systemic diseases. In addition to general health conditions, the limitations of the elderly in obtaining health services, including oral health services, will have implications for the health of the periodontal tissue.

\section{PERIODONTAL CONSIDERATIONS IN THE ELDERLY}

Aging is a complex biological phenomenon that results from interactions between genetic and environmental factors. This process can directly or indirectly increase the risk of disease progression. As people get older, more systemic diseases are diagnosed, requiring the use of medications. The most common systemic diseases found in the elderly are arthritis, neck and head cancer, chronic respiratory obstruction, diabetes mellitus, mental illness, cardiovascular disease, hypertension, osteoporosis, Parkinson's disease, and cerebrovascular accidents. ${ }^{30,31}$

Aging is a process of physiological and biological changes that will happen to every human being. This aging process is greatly influenced by the economy, environment, society, and the rapid development of treatment. The aging process causes changes in the mouth. Changes in the oral epithelium due to the aging process are associated with epithelium depletion and decreased keratinization of the gingival epithelium. Changes that occur in the periodontal tissue include changes in the cementum, alveolar bone, and periodontal ligament. Changes to the cementum occur in the form of local resorption on the cementum surface. This is followed by cementum apposition, which increases with age..$^{11,12}$

Changes due to aging also occur in the alveolar bone. Bone formation continues to decline as one ages, which results in easier loss of bone mass so that bone resorption occurs. The connective tissue component of the periodontal ligament also experiences changes due to aging. Changes in the periodontal ligament associated with aging include reduced fibroblasts with more irregular structure, reduced organic matrix production, epithelial cell residue, and increased amount of elastic 
fibers. Loss of attachment and resorption of alveolar bone occur as a result of frequent exposure to other risk factors. The risk factors that influence the development of periodontal disease in the elderly include systemic diseases, such as diabetes mellitus and osteoporosis, systemic conditions, such as metabolic syndrome, treatment of systemic diseases, and limited access to dental and oral care. ${ }^{32,33}$

An increase in age is directly and proportionally associated with an increase in the prevalence and severity of periodontal disease. In addition, an increase in age causes a decrease in motoric function and an increase in comorbidities and the treatment of diseases in the elderly. ${ }^{30}$ Periodontal treatment in the elderly often does not achieve its expected results due to the improper care provided to the elderly. In Indonesia, the elderly obtain special oral health services because the characteristics of their oral and systemic conditions are different from younger adults. It is important for periodontal treatment in the elderly to pay attention to the other risk factors associated with periodontal disease.

One systemic disease that is closely related to periodontal disease is diabetes mellitus. According to Preshaw et al., there is no doubt that periodontal disease plays an important role in the severity of diabetes mellitus and vice versa. This is also consistent with research conducted by Negrato et al. and Dharmawati and Raiyanti. Many studies related to the prevalence of periodontal disease in elderly people with diabetes mellitus have been conducted. One of them is a study conducted by Grossi et al. that suggested that the prevalence of periodontal disease in people with diabetes mellitus increases with age. However, it is necessary to understand that changes in the oral tissue due to the aging process may also have a role in causing periodontal disease. ${ }^{34-37}$

This is similar to other systemic diseases or systemic conditions that are associated with periodontal disease in the elderly, such as osteoporosis, obesity, metabolic syndrome, and stress. According to Aljehani and Genco and Borgnakke, the diseases and systemic conditions mentioned above were modifiable risk factors for periodontal disease. However, there is no further explanation of how the effect of the systemic disease or systemic condition influences periodontal disease based on age. It is understood that age is one of the risk factors for periodontal disease that cannot be modified. Therefore, endurance and physical fitness may have an important role in slowing the development and reducing the severity of periodontal disease. This may be due to the fact that younger patients with systemic disease more readily seek treatment than elderly patients with periodontal disease. . $^{13,16,37}$
The various risk factors that influence periodontal disease make it important for the management of periodontal disease in elderly patients to be multidisciplinary and more comprehensive. The existence of a two-way relationship between some systemic diseases and periodontal disease certainly requires that special attention be paid to not only periodontal disease but also systemic disease. This also applies to medications consumed by the elderly. Medication treatment in elderly patients can affect their periodontal condition. In such cases, the dentist should work together with an internist who treats elderly patients. Consideration should also be given to medications that do not have interactions with other drugs that are being consumed by elderly patients.

Some literature states that the elderly generally respond to periodontal therapy, which is similar to the response in young adults. ${ }^{6}$ However, as the patient ages, a number of obstacles arise that require the dentist's attention. These obstacles include decreased physical activity, chronic medical conditions, and the use of various types of medications. The dentist must carefully review the patient's medical history and prescribe medications wisely to prevent unwanted drug interactions. It is also important to consider that the physical limitations of the elderly can be a barrier to periodontal treatment. Therefore, chemical agents, such as stannous fluoride, should be added to toothpaste so that it can reduce plaque better than using fluoride toothpaste alone. For most people, tooth brushing must be complemented by interproximal cleaning. With aging and decreased dexterity, flossing becomes more difficult. Therefore, the use of wood sticks and inter-dental brushes is easier and more effective than dental floss. ${ }^{6}$

Another factor that influences the development and severity of periodontal disease in the elderly is limitations in access to health care facilities. This is consistent with the opinion of Bersell from the American Dental Hygienists' Association, who put forward that easy access to essential dental care is vital to maintain oral health in vulnerable populations, especially children, pregnant women, and the elderly. However, according to research by Slack-Smith et al., limitations for the elderly in accessing dental health care are not solely physical but can also originate from past trauma in receiving dental care as well as limited financial and insurance resources. ${ }^{38,39}$

The important point to understand is that all of the factors that have been explained above can basically affect the development and severity of periodontal disease regardless of age, whether it be young people or the elderly. However, it becomes more relevant due to the physical, physiological and psychological changes, and immune system changes that occur in elderly. Given 
the multiple factors that influence the development and severity of periodontal disease in the elderly, special treatment is needed for elderly patients.

\section{CONCLUSION}

In addition to having physical limitations, elderly people often have a variety of chronic medical conditions and take multiple medications. At the same time, they often have poor oral hygiene and periodontal disease, so appropriate care is needed. Periodontal disease in the elderly is influenced by various risk factors. These multiple risk factors make periodontal treatment important in elderly patients and require special treatment involving multidisciplinary teams. Good communication between the dentist and the physician who treats the general condition of elderly patients is very important in the management of elderly patients who have complex medical conditions.

\section{REFERENCES}

1. Indonesia. Populasi lansia diperkirakan terus meningkat hingga tahun 2020 [Internet]. Jakarta: Kementrian Kesehatan RI; 2013. [cited 2019 August 8]. Available from: http://www.depkes.go.id/article/ view/13110002/populasi-lansia-diperkirakan-terusmeningkat-hingga-tahun-2020.html

2. Indonesia. Indonesia masuki periode aging population [Internet]. Jakarta: Kementrian Kesehatan RI; 2019 [cited 2019 August 12]. Available from: http://www.depkes.go.id/article/view/19070500004/i ndonesia-masuki-periode-aging-population.html

3. Zein RPS, Rachmadi P, Putri DKT. Tingkat kebutuhan perawatan periodontal pada lansia di Panti Sosial Tresna Werdha Budi Sejahtera Banjarbaru. Dentino Jurnal Kedokteran Gigi. 2014;2(2):189-195.

4. Permana FH, Made S, Imron R. Hubungan penurunan fungsi gerak lansia terhadap strategi koping stres lansia di Panti Jompo Welas Asih Kecamatan Singaparna Kabupaten Tasikmalaya. Jurnal Keperawatan Soedirman. 2009;4(3):125-130.

5. Sharma S, Manjit T, Gaurav M. Prevalence of dental caries and periodontal disease in the elderly of chandigarh - A hospital based study. J Indian Assoc. 2012;6(2):78-82.

6. Darby I. Periodontal considerations in older individuals. Aust Dent J. 2015;60:14-19.

7. World Health Organization. The WHO global oral health data bank [Internet]. Geneva: WHO; 2007 [cited on 2019 Augus 12]. Available from: http://www.who.int/oral health.

8. Tang I. Clinical analysis of the aged with periodontitis community health. Guide Chin Med.
2012;36(4):185-186.

9. Petersen PE, Kandelman D, Arpin S, Ogawa H. Global oral health of older people. Community Dental Health. 2010;27(2):257-268.

10. Yang H, Xiao L, Zhang L, Deepa S, Ye G, Zhang X. Epidemic trend of periodontal disease in eldery Chinese population 1987-2015: a systematic review and meta-analysis. Sci Rep. 2017;7:1-11.

11. Genco RJ, Borgnakke WS. Risk factors for periodontal disease. Periodontol 2000. 2013; 62(1):59-94.

12. Beikler T, Flemmig TF. Oral biofilm-associated diseases: Trends and implications for quality of life, systemic health and expenditures. Periodontol 2000. 2011;55:87-103.

13. Yu-Kang T, Gilthorpe MS. Comentary: Is tooth loss good or bad for general health? Int J Epidemiol. 2005;34:475-476.

14. Aljehani YA. Risk factors of periodontal disease: review of the literature [Internet]. Int J Dent. 2014;2014:182513.

15. Foltyn P. Ageing, dementian, and oral health. Australian Dental Journal. 2015;60(1):86-94.

16. Ettinger RL. Treatment planning concepts dor te ageing patient. Australian Dental Journal. 2015;60(1):71-85.

17. Nazir MA. Prevalence of periodontal disease, its association with systemic disease and prevention. Int J Health Sci. 2017;11(2):72-80.

18. International Diabetes Federation. Diabetes Atlas $4^{\text {th }}$ Ed [Internet]. Brussel: International Diabetes Federation. 2009 [cited 2019 August 23]. Available from: https://www.idf.org/e-library/epidemiologyresearch/diabetes-atlas/21-atlas-4th-edition.html

19. Corbet EF, Leung WK. Epidemiology of periodontitis in the Asia and Oceania Regions. Periodontol 2000. 2011;56(1):25-64.

20. Boehm TK, Scannapieco SA. The Epidemiology, consequences and management of periodontal disease in older adults. J Am Dent Assoc. 2008;139(3):252-253.

21. Simpson TC, Weldon JC, Worthington HV, Needleman I, Wild SH, Moles DR, et al. Treatment of periodontal disease for glycaemic control in people with diabetes mellitus [Internet]. Cochrane Database of Systematic Reviews. 2015 [cited 2019 August 27]. Available from: https://www.cochrane library.com/cdsr/doi/10.1002/14651858.CD004714.p ub3/epdf/full

22. Kyrgidis A, Tzellos TG, Toulis K, Antoniades K. The Facial Skeleton in Patients with Osteoporosis: A Field for Disease Signs and Treatment Complications [Internet]. J of Osteoporosis; 2011 [cited 2019 August 27]. Available from: https:// www.hindawi.com/journals/jos/2011/147689/\#B1 
23. Tiossi R, Costa PP, Watanabe PCA. The Influence of Osteoporosis in Oral Health. In Osteoporosis: Risk Factors, Symptoms and Management. Pena AR, Perez VO (eds). Nova Science Publisher, Brazil. 2012, pp.1-32.

24. Razak PA, Richard KMJ, Thankachan RP, Hafiz KAA, Kumar KN, Sameer KM. Geriatric oral health: A review article. J Int Oral Health. 2014;6(6):110116.

25. Bhardwaj A, Bhardwaj SV. Effect of menopause on women's periodontium. J Midlife Health. 2012;3(1):5-9.

26. Silva RF, Sasso GRD, Cerri ES, Simoes MJ, Cerri PS. Biology of bone tissue: structure, function, and factors that influence bone cells [Internet]. Biomed Research Int. 2015. [cited 2019 August 16]. Available from: https://www.hindawi.com/journals/ bmri/2015/421746/

27. Salazar CR. The role of stress in periodontal disease progression in older adults. Postdoc Journal. 2013;1(11):15-26.

28. Dahiya P, Kamal R, Gupta R. Obesity, periodontal and general health : Relation and management. Indian J Endocrinol Metab. 2012;16(1):88-93.

29. Aboy, Soulissa AG. Perbedaan status periodontal antara obesitas dan non-obesitas. Jurnal Ilmiah Kedokteran Gigi Terpadu. 2017;3(2):70-73.

30. Paredes-Rodríguez VM, Torrijos-Gómez G, González-Serrano J, López-Pintor-Muñoz RM, López Bermejo M ángel, Hernández-Vallejo G. Quality of life and oral health in elderly. J Clin Exp Dent. 2016;8(5):590-596.

31. Holm-Pedersen P, Walls A, Ship J. Textbook of geriatric medicine. 3rd Ed. Oxford: Wiley Blackwell; 2015. p. 61-64.

32. Huttner EA, Machado DC, Oliveria RB, Antunes AGF, Hebling E. Efects of human aging on periodontal tissues. Spec Care Dentist. 2009;29(4):149-153.

33. Bhadbhade S. Aging and periodontium. Int $\mathbf{J}$ Dent Oral Sci. 2015;2(6):79-83.

34. Preshaw PM, Alba AL, Herrera D, Jepsen S, Konstantinidis A, Makrilakis K, et al. Periodontitis and diabetes: a two-way relationship. Diabetologia. 2012;55(1):21-31.

35. Negrato CA, Tarzia O, Jovanovic L, Chinellato LEM. Periodontal disease and diabetes mellitus. J Appl Oral Sci. 2013;21(1):1-12.

36. Dharmawati IGAA, Raiyanti IGA. Hubungan antara faktor resiko (umur dan jenis kelamin) dengan kelainan jaringan periodontal pada penderita diabetes melitus yang berkunjung ke poliklinik penyakit dalam RSUD Sanjiwani Gianyar Tahun 2014. Jurnal Kesehatan Gigi. 2015;3(2):61-65.

37. Grossi SG, Genco RJ. Periodontal disease and diabetes mellitus: A two-way relationship. Annals of Periodontol. 1998; 3(1): 51-61.

38. Bersell CH. Access to Oral Health Care: A National Crisis and Call for Reform. J of Dental Hygiene. 2017; 91(1): 6-14.

39. Slack-Smith L, Lange A, Paley G, O’Grady M, French D, Short L. Oral health and access to dental care: a qualitative investigation among older people in the community. Gerodontology. 2010; 27(2): 104113. 